Article

\title{
Facile Synthetic Route of a Solution-Processable, Thieno[3,4-c]pyrrolo-4,6-dione-Based Conjugated Small Molecule and Control of the Optoelectronic Properties via Processing Additives
}

\author{
Obum Kwon ${ }^{1}$, Jihyun Lim ${ }^{2}$, Jin Kuen Park ${ }^{3, *}$ and Dong Hwan Wang ${ }^{2, *}$ \\ 1 Miwon Commercial, 49 Wonsiro, Danwongu, Ansan 15610, Gyeonggi-do, Korea; obkwon@mwc.co.kr \\ 2 School of Integrative Engineering, Chung-Ang University, 84 Heukseok-Ro, Dongjak-gu, Seoul 06974, Korea; \\ hyun2018@cau.ac.kr \\ 3 Department of Chemistry, Hankuk University of Foreign Studies, Yongin 449-791, Gyeonggi-do, Korea \\ * Correspondence: jinkpark@hufs.ac.kr (J.K.P.); king0401@cau.ac.kr (D.H.W.)
}

Received: 1 November 2018; Accepted: 13 December 2018; Published: 17 December 2018

\begin{abstract}
In this study, a new type of low-bandgap small molecule has been synthesized with a thieno[3,4-c]pyrrole-4,6-dione (TPD) derivative for application in bulk heterojunction (BJH) solar cells. The series of solar cells were fabricated by blending the TPD-based small molecule (M1) and $[6,6]$-phenyl $C_{71}$ butyric acid methyl ester $\left(\mathrm{PC}_{71} \mathrm{BM}\right)$. In order to optimize the performance of solar cells, the nanoscale morphologies of the $\mathrm{BHJ}$ layers were controlled via processing additives with 1,8-diiodooctane (DIO) and 1-chloronaphthalene $(\mathrm{CN})$. Therefore, we demonstrated that the use of $\mathrm{CN}$ successively suppressed molecular aggregation and demonstrated suitable phase separation, in addition to increasing the power conversion efficiency from $0.36 \%$ to $1.86 \%$.
\end{abstract}

Keywords: thieno[3,4-c]pyrrole-4,6-dione; small molecule bulk heterojunction solar cell; processing additive; morphology; low-bandgap conjugated molecules

\section{Introduction}

Solution-processed organic solar cells have been studied due to the social demand of low-cost, lightweight, flexible, and printable devices in large scale [1-5]. Significant progress of organic solar cells has been demonstrated by utilizing a bulk heterojunction (BHJ) strategy consisting of narrow-bandgap conjugated polymers as p-type semiconductors and fullerene derivatives as n-type semiconductors, [6-13] leading to desirable, nanoscale phase separation of the two organic components and the achievement of a high power conversion efficiency (PCE) [14-17]. In order to optimize such a BHJ solar cell system, many efforts have been mainly focused on developing novel, p-type conjugated polymers because of their unique light-harvesting properties, good film formation, and extended electron delocalization through their backbone structures synthesized by alternative copolymerization with electron donor (D) and acceptor (A) units, which can lead to good charge carrier mobilities and narrow energy band gaps [18-24]. However, the intrinsically broad polydispersity of their molecular weights often limit their purification, reproducibility of performance, and cause significant batch-to-batch variation of the performance in functioning devices [25].

Conversely, solution-processed conjugated small molecules have attracted significant attention as candidates for active materials in $\mathrm{BHJ}$ solar cells as p-type semiconductor components due to their well-defined molecular structures and molecular weights and their easy purification methods [25-30]. Thus, various types of small molecules such as organic dyes, [31-35] oligothiophenes, [36-40] and D-A type molecules have been designed and synthesized to optimize the BHJ solar cell systems [41-45]. 
However, most of them showed low PCEs because it is still difficult to obtain the desirable phase separation morphologies of those two organic components. Therefore, there is a high demand for the discovery of more applicable molecular structures to the BHJ systems and thus, the design and synthesis of appropriate molecules for efficient performance still merits extensive research $[25,26]$. Recently, extended D-A structures such as D-A-D-A-D-type conjugated small molecules have been considered as the most successful alternatives to polymers for BHJ solar cells, comprising nearly $10 \%$ of PCEs since the choice of D and A units and conjugated length of the framework can tailor thermal properties, optical properties, and ordered self-assemblies in their solid states [46-51].

Currently, electron-deficient thieno[3,4-c]pyrrole-4,6-dione (TPD) units have been developed as very promising building blocks for conjugated polymers for effective BHJ solar cells $[9,10,13,17,51-56]$. Each TPD unit has a relatively strong electron-withdrawing property which can lower the highest occupied molecular orbital (HOMO) level of the polymeric materials against the vacuum level and then, increase open circuit voltage $\left(V_{\mathrm{oc}}\right)$ in $\mathrm{BHJ}$ solar cells when it is fabricated with phenyl- $\mathrm{C}_{61}$ or $\mathrm{C}_{70}$-butyric acid methyl ester (PCBM) derivatives [57-59]. Recent reports of BHJ solar cells employing TPD-based polymers have achieved PCEs up to 8.5\% [17]. However, TPD-based molecules have yet to be extensively investigated as materials for small molecule(SM)-BHJ solar cells. In 2012, Lin et al. reported a series of TPD(A)-based p-type organic semiconductors conjugated with triphenylamine (D) showing D-A-D structures that exhibited a PCE of 3.3\% from functioning BHJ solar cell systems [60].

Even though the D-A-D structures with TPD units showed quite successful performances, we believe that a D-A-D-A-D strategy can provide more structural diversity than a D-A-D strategy. Therefore, in this work, we prepared a new TPD-based small molecule bearing the D-A-D-A-D framework consisting of electron-donating bithiophene and electron-accepting TPD units. The thermal, optical, and electrochemical properties of the molecule were characterized, and the photovoltaic performances of devices fabricated under different conditions were also evaluated.

\section{Materials and Methods}

\subsection{Materials}

All chemicals and reagents were purchased from Sigma-Aldrich (St. Louis, MO, USA), Alfa Aesar (Heverhill, MA, USA), or TCI America (Tokyo, Japan) and used directly as received. Thiophene dicarboxylic acid was purchased from Frontier Scientific Inc. (Logan, UT, USA) and used without further purification. The synthetic route to 1,3-dibromo-5-(2-ethylhexyl)-thieno[3,4-c]pyrrole-4,6-dione was adapted from a previously published procedure, as described below [52].

\subsection{Synthesis and Characterization}

\subsubsection{5-(2.-Ethylhexyl)-thieno[3,4-c]pyrrole-4,6-dione}

In a $250 \mathrm{~mL}$ flame-dried round bottom flask equipped with a cooling condenser, $3.44 \mathrm{~g}(20 \mathrm{mmol})$ of thiophene dicarboxylic acid was mixed with $100 \mathrm{~mL}$ of acetic anhydride. The mixture was stirred vigorously at $140{ }^{\circ} \mathrm{C}$ for $16 \mathrm{~h}$ (overnight). The temperature was then decreased to $75^{\circ} \mathrm{C}$ and unreacted acetic anhydride was distilled off under a reduced pressure. The remaining crude, dark-brown solid was carried through to the next synthetic step without further purification. Then, $100 \mathrm{~mL}$ of toluene was added to the flask and $3.88 \mathrm{~g}(30 \mathrm{mmol})$ of 2-ethyl-1-hexylamine was added dropwise. The mixture was stirred at $120^{\circ} \mathrm{C}$ for $20 \mathrm{~h}$ (overnight). After being cooled down to room temperature, the solvent was removed using a rotary evaporator (EYELA, Tokyo, Japan). For the next step, $30 \mathrm{~mL}$ of thionyl chloride was added to the crude solid. The mixture was stirred at $75^{\circ} \mathrm{C}$ for $3 \mathrm{~h}$. After being cooled to room temperature, the solution was slowly pipetted into $300 \mathrm{~mL}$ of water, causing precipitation of a brown solid. The crude solid was recovered by filtration and washed with water. Next, the product was purified by silica gel column chromatography using a dichloromethane/hexane gradient. Finally, the product was collected and dried, resulting in a white solid. Overall yield: $4.4 \mathrm{~g}(16.58 \mathrm{mmol}$, 
83\%). 1H-NMR (400 MHz, chloroform-d, 8$): 7.67$ (s, 2H, CH), 3.51 (t, 2H, CH2), 1.81-1.77 (m, 1H, CH), 1.38-1.21 (br m, 8H, CH2), and 0.94-0.87 (br m, 6H, CH3). HRMS (EI) m/z, calculated for C14H19NO2S $(\mathrm{M}+)$ : 265; found: 265 .

\subsubsection{1,3-Dibromo-5-(2-ethylhexyl)-thieno[3,4-c]pyrrole-4,6-dione (6)}

In a $250-\mathrm{mL}$ flame-dried round bottom flask, $4.4 \mathrm{~g}(16.58 \mathrm{mmol})$ of 5-(2-ethylhexyl)-thieno[3,4c]pyrrole-4,6-dione was dissolved with $50 \mathrm{~mL}$ of trifluoroacetic acid and $15 \mathrm{~mL}$ of sulfuric acid. When the mixture became a clear solution, $8.85 \mathrm{~g}(50 \mathrm{mmol})$ of $\mathrm{N}$-bromosuccinimide was added in small portions. The mixture was stirred overnight at room temperature. The brownish red solution was diluted with water $(100 \mathrm{~mL})$ and the organic components were extracted with dichloromethane and washed with water three times. The organic phase was then dried over magnesium sulfate, followed by the removal of solids by filtration. After removing the volatile solvent under reduced pressure, purification was accomplished by silica gel column chromatography using dichloromethane and hexane (1:2) mixture as the eluent, resulting in a white solid. Recovered yield: $5.7 \mathrm{~g}(13.47 \mathrm{mmol}, 81 \%)$. 1H-NMR (400 MHz, chloroform-d, 8$): 3.51$ (t, 2H, CH2), 1.81-1.77 (m, 1H, CH), 1.38-1.21 (br m, 8H, $\mathrm{CH} 2$ ), and 0.94-0.87 (br m, 6H, CH3). HRMS (EI) m/z, calculated for C14H17Br2NO2S (M+): 420; found: 420 .

\subsubsection{1-Bromo-5-(2-ethylhexyl)-thieno[3,4-c]pyrrole-4,6-dione (7)}

In a 250-mL flame-dried three-neck round bottom flask equipped with a water condenser, $2.0 \mathrm{~g}$ $(4.8 \mathrm{mmol})$ of 1 was mixed with $30 \mathrm{~mL}$ of ethanol, $10 \mathrm{~mL}$ of acetic acid, and three drops of hydrochloric acid $(1 \mathrm{~N})$, and this mixture was heated to $60^{\circ} \mathrm{C}$ until a homogeneous solution was obtained. Then, $320 \mathrm{mg}$ ( $4.8 \mathrm{mmol}$ ) of zinc dust was added and the mixture was stirred at $80^{\circ} \mathrm{C}$ for $3 \mathrm{~h}$. After being cooled down to room temperature, the solid residue was recovered by filtration and the residual solvent was removed under reduced pressure, resulting in a crude yellow solid. Next, the crude product was dissolved in diethyl ether and washed two times with water and one time with a saturated, aqueous solution of sodium bicarbonate. The organic phase was then separated and dried over magnesium sulfate. Purification was accomplished by silica gel column chromatography using a dichloromethane/hexane gradient. Finally, the collected portion was dried by evaporation, resulting in a white solid. Recovered yield: $830 \mathrm{mg}(2.4 \mathrm{mmol}, 50 \%)$. 1H-NMR (400 MHz, chloroform-d, $\delta): 7.67$ (s, $1 \mathrm{H}, \mathrm{CH}), 3.51(\mathrm{t}, 2 \mathrm{H}, \mathrm{CH} 2), 1.81-1.77(\mathrm{~m}, 1 \mathrm{H}, \mathrm{CH}), 1.38-1.21$ (br m, 8H, CH2), and 0.94-0.87 (br m, $6 \mathrm{H}, \mathrm{CH} 3$ ). HRMS (EI) $\mathrm{m} / \mathrm{z}$, calculated for C14H18BrNO2S (M+): 343; found: 343.

\subsubsection{5,5'-Bis(5-(2-ethylhexyl)-thieno[3,4-c]pyrrole-4,6-dione)-2,2'-bithiophene (8)}

A 20-mL Biotage microwave vial was charged with $2(282.3 \mathrm{mg}, 0.82 \mathrm{mmol})$, 5,5'-bis(tributylstannyl)-2,2'-bithiophene (297.7 mg, $0.4 \mathrm{mmol}), \mathrm{Pd}(\mathrm{PPh} 3) 4$ (46 mg, $0.04 \mathrm{mmol}$ ), and toluene $(12 \mathrm{~mL})$. The vial was then sealed with a Teflon cap under a nitrogen atmosphere and placed in a Biotage microwave reactor (Biotage, Uppsala, Sweden). Next, the reaction mixture was heated to $170{ }^{\circ} \mathrm{C}$ for $1 \mathrm{~h}$. Once cooled, the mixture was poured into $200 \mathrm{~mL}$ of methanol and the precipitate formed was filtered and dissolved in a small amount of dichloromethane. The solution was loaded onto silica gel and purified by flash chromatography using a dichloromethane/hexane gradient. Finally, the fraction was collected and dried, resulting in a red solid. Recovered yield: $200 \mathrm{mg}(72 \%)$. 1H-NMR (400 MHz, chloroform-d, 8$): 7.95(\mathrm{~d}, 2 \mathrm{H}, \mathrm{CH}), 7.66(\mathrm{~s}, 2 \mathrm{H}, \mathrm{CH}), 7.29(\mathrm{~d}, 2 \mathrm{H}, \mathrm{CH}), 2.76(\mathrm{t}, 4 \mathrm{H}$, CH2), 1.86-1.78 (br m, 2H, CH), 1.42-1.23 (br m, 16H, CH2), and 0.98-0.83 (br m, 12H, CH3). LRMS (FD) $\mathrm{m} / \mathrm{z}$, calculated for C36H40N2O2S4 (M+): 692; found: 692.

2.2.5. 5,5'-Bis $\left\{3-\left(5^{\prime}\right.\right.$-hexyl-2,2'-bithiophene-5-yl)-5-(2-ethylhexyl)-thieno[3,4-c]pyrrole-4,6-dione\}2,2'-bithiophene (M1)

A 5-mL Biotage microwave vial was charged with $3(173.4 \mathrm{mg}, 0.25 \mathrm{mmol})$, 5-bromo-5'-hexyl-2,2'-bithiophene $(181.1 \mathrm{mg}, 0.55 \mathrm{mmol})$, trans-di( $\mu$-acetato)bis[o-(di-o-tolyl- 
phosphino)benzyl]dipalladium(II) (4.71 mg, $4 \mathrm{~mol} \%$ ), tris(o-methoxyphenyl)phospine (7.04 mg, $8 \mathrm{~mol} \%)$, cesium carbonate $(162.9 \mathrm{mg}, 0.5 \mathrm{mmol})$, and tetrahydrofuran $(2 \mathrm{~mL})$. The vial was then sealed with a Teflon cap under nitrogen atmosphere and placed in an oil bath. Next, the reaction mixture was heated to $120^{\circ} \mathrm{C}$ for $24 \mathrm{~h}$ with vigorous stirring. Once cooled, the mixture was poured into $200 \mathrm{~mL}$ of methanol and the precipitate was filtered and loaded onto silica gel for purification by flash chromatography using a dichloromethane/hexane gradient. Finally, the fraction was collected and dried, resulting in a dark purple solid. Recovered yield: $152 \mathrm{mg}$ (51\%). 1H-NMR (600 MHz, 1,1,2,2-tetrachloroethane-d2, 8$): 7.86(\mathrm{~d}, 4 \mathrm{H}, \mathrm{CH}), 7.14(\mathrm{~d}, 2 \mathrm{H}, \mathrm{CH}), 7.05(\mathrm{~d}, 2 \mathrm{H}, \mathrm{CH}), 7.00$ (d, 2H, CH), $6.70(\mathrm{~d}, 2 \mathrm{H}, \mathrm{CH}), 3.54(\mathrm{~d}, 4 \mathrm{H}, \mathrm{CH} 2), 2.78(\mathrm{t}, 4 \mathrm{H}, \mathrm{CH} 2) 1.87$ (br m, 2H, CH), 1.71-1.64 (br m, 4H, CH2), 1.42-1.29 (br m, 28H, CH2), and 0.97-0.89 (br m, 18H, CH3). 13C-NMR (125 MHz, 1,1,2,2-tetrachloroethane-d2, $\delta$ ppm): 162.20, 146.82, 141.14, 138.93, 135.72, 134.33, 133.37, 131.92, 130.91, 130.43, 129.80, 128.29, 127.56, 124.86, 124.42, 123.47, 42.45, 37.97, 31.46, 31.21, 30.46, 30.06, 29.62, 28.80, 28.46, 23.72, 23.12, 22.53, 14.11, and 10.44. Elemental Analysis: Calculated (mass \%) for C64H72N2O4S8: C, 63.64; H, 7.51; N, 2.32; O, 5.30; S, 21.24. Found: C, 64.4; H, 6.18; and N, 2.51. LRMS (FD) $\mathrm{m} / \mathrm{z}$, calculated for C64H72N2O4S8 (M+): 1188; found: 1188.

\subsection{Solar Cell Fabrication and Characterization}

In this work, solar cells were fabricated with the following device architecture: ITO/PEDOT:PSS/ M1:PC71BM/Al. Prior to use, ITO substrates were cleaned by sonication separately in soapy water, acetone, and isopropyl alcohol; dried in an oven (Wisd, Dublin, Ireland); then subjected to ultraviolet (UV)/ozone treatment. A $40 \mathrm{~nm}$ thick poly(3,4-ethylenedioxythiophene): polystyrene sulfonate (PEDOT:PSS) layer was spun cast from aqueous solution (5000 rpm for $40 \mathrm{~s}$ ). The substrates were then dried at $140{ }^{\circ} \mathrm{C}$ for $10 \mathrm{~min}$ in air and transferred to a N2-glovebox for spin-casting of the active layers. Solar cells were fabricated using $\mathbf{M 1}$ as the donor and [6,6]-phenyl C71 butyric acid methyl ester (PC71BM) as the acceptor. Solutions of M1:PC71BM with different ratios (30:70, 40:60, 50:50, 60:40, and 70:30 $w / v)$ in chloroform, and solutions with an optimized blend ratio $(40: 60 w / v)$ in chlorobenzene with or without additives were spun cast onto the substrates. The final step in device construction involved the thermal evaporation of the $100 \mathrm{~nm}$ thick $\mathrm{Al}$ electrodes. All data were obtained under AM $1.5 \mathrm{G}$ illumination from a calibrated solar simulator with an irradiation intensity of $100 \mathrm{~mW} / \mathrm{cm}^{2}$ under an ambient atmosphere. For each case, five devices were fabricated and each device had two electrodes on top.

\section{Results and Discussion}

\subsection{Molecular Design and Synthesis}

Scheme 1 shows the chemical structure of the target molecule (M1) and Scheme 2a depicts synthetic strategy for $\mathbf{M} 1$ by showing several steps of the retrosynthesis. Since bithiophene derivatives such as 1 and 3 in Scheme 2a are commercially available, it would be convenient that based on bithiophene derivatives, the other groups were retrosynthetically analyzed first and then, since each molecule could be coupled by two types of well-established reaction depending on the type of bithiophene derivatives, as shown in Scheme 1a, we believed that the analysis was correct and feasible. Further retrosynthetic analysis was focused on the other side group containing TPD units such as 2 and 4 as described in Scheme $2 \mathrm{~b}$. Since the hexyl bithiophene derivative notated as 5 is also commercially available, the 2 and 4 can be retrosynthetically analyzed by two parts such as TPD derivatives and 5, as shown in Scheme 2b. From this aspect, it was found that the mono-brominated TPD (7 in Scheme 2b) and bis-brominated TPD ( 6 in Scheme $2 b$ ) formed the possible starting point for the desired M1 molecule. Therefore, 1,3-dibromo-5-(2-ethylhexyl)-thieno[3,4-c]pyrrole-4,6-dione (6) was prepared with a yield of $65 \%$ by following the literature, as shown in Scheme 3a [53]. Then, one of the bromine substituents on 6 was reduced with zinc (0) so as to afford 7 with a yield of $56 \%$, see Scheme $3 a$. Then, 2 was synthesized upon varying the stoichiometric ratio of 6 and 5 via a Stille cross-coupling reaction as 
shown in Scheme 3b. However, most of the resulting product was insoluble polymeric solid, resulting in a yield of 2 of only $7 \%$ even though an excess amount of 6 was used. Therefore, it was found that this type of reaction was not an atom economically favorable method to get 2 especially. Nonetheless, a quite reasonable amount of 4 was obtained via direct heteroallylation with a 1:1 stoichiometric ratio of 5 and 7, such as mono-brominated TPD. At this point, we lack insight to explain the side reaction in Scheme $3 \mathrm{~b}$ via a Stille cross-coupling reaction but it is worthy to note here that TPD derivatives seem to be more suitable and stable for the direct heteroallylation condition. After 4 was obtained, several trials were attempted to obtain 2 by brominating 4 with $\mathrm{N}$-bromosuccinimide (NBS), as displayed in Scheme 3c. However, Fragment 2 was not obtained from any of the trials. Notably, too many spots were detected on thin layer chromatography (TLC) substrates when the bromination was processed in the acidic condition where the TPD units were brominated. Therefore, further analysis of resulting compounds from such an acidic condition was almost impossible and we concluded that the starting materials, such as 4 , could be decomposed in such acidic conditions. In relatively mild conditions, almost all starting materials remained intact for $12 \mathrm{~h}$ without showing any significant conversion to brominated compounds based on TLC analysis.

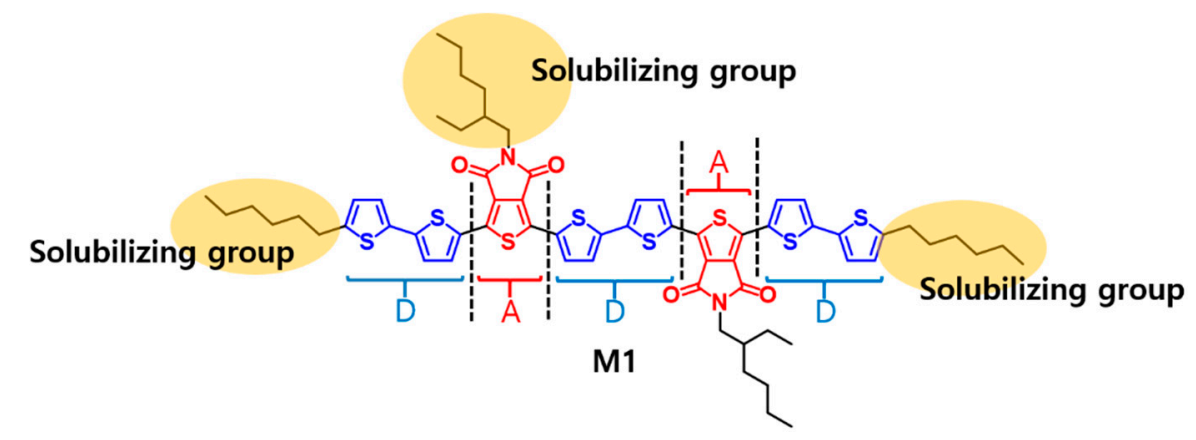

Scheme 1. The schematic illustration of the target structure for new type of D-A-D-A. D = donor unit; $\mathrm{A}=$ acceptor unit.

a)

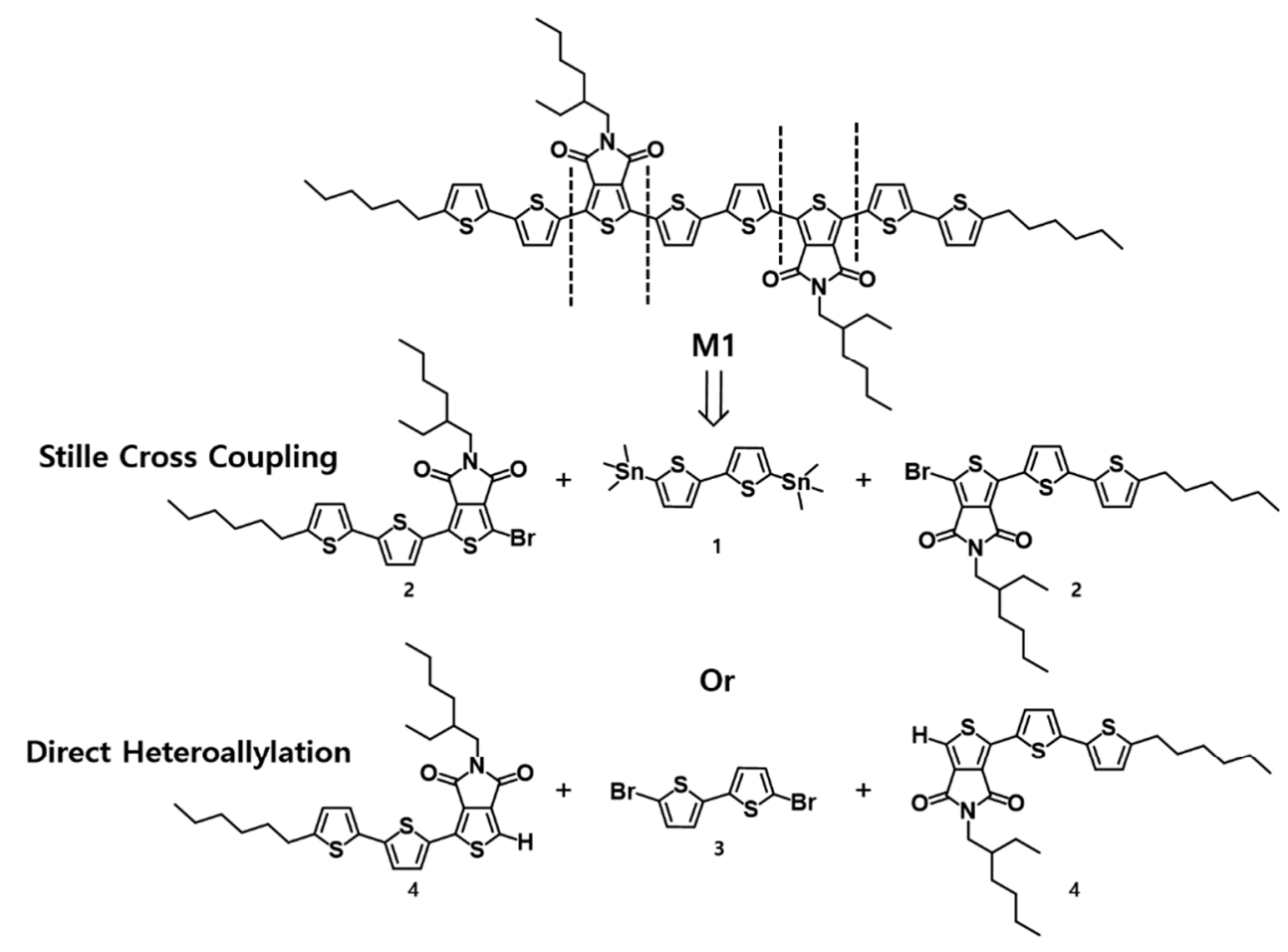

Scheme 2. Cont. 
b)

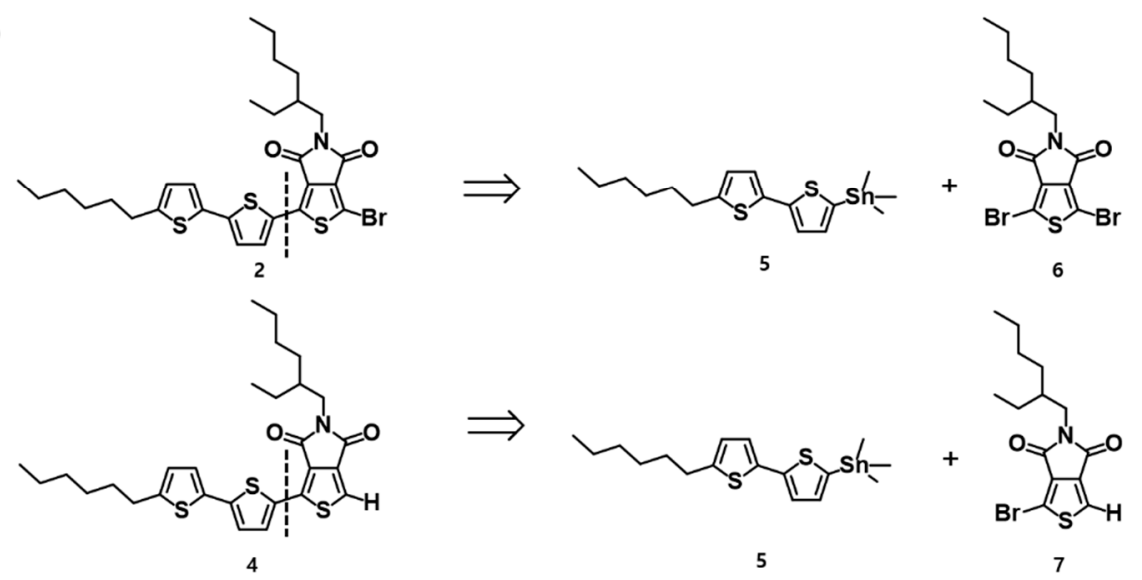

Scheme 2. (a) Structure of M1 having a D-A-D-A-D framework with two principle restrosynthetic approaches and $(\mathbf{b})$ retrosynthetic routes to obtain certain molecules according to the synthetic strategies for the target molecule M1.

a)

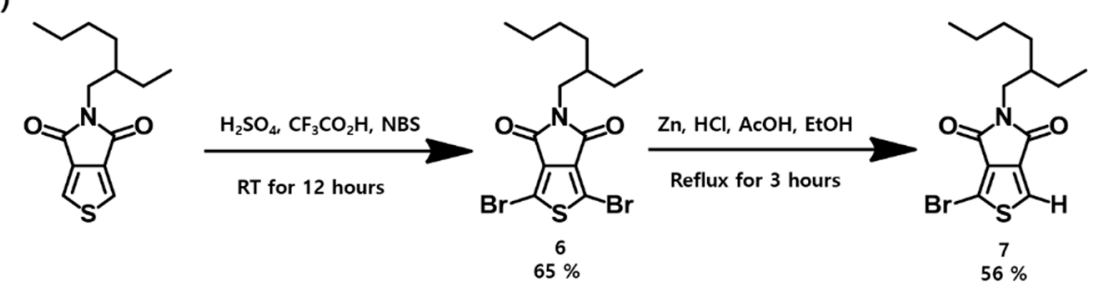

b)

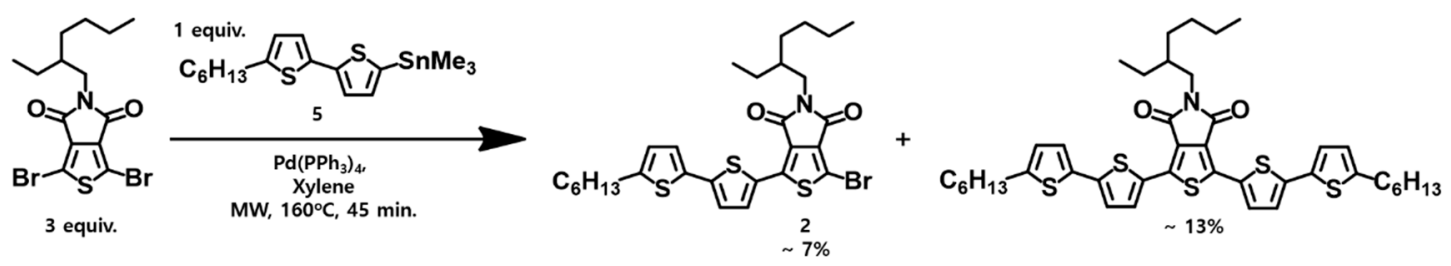

C)

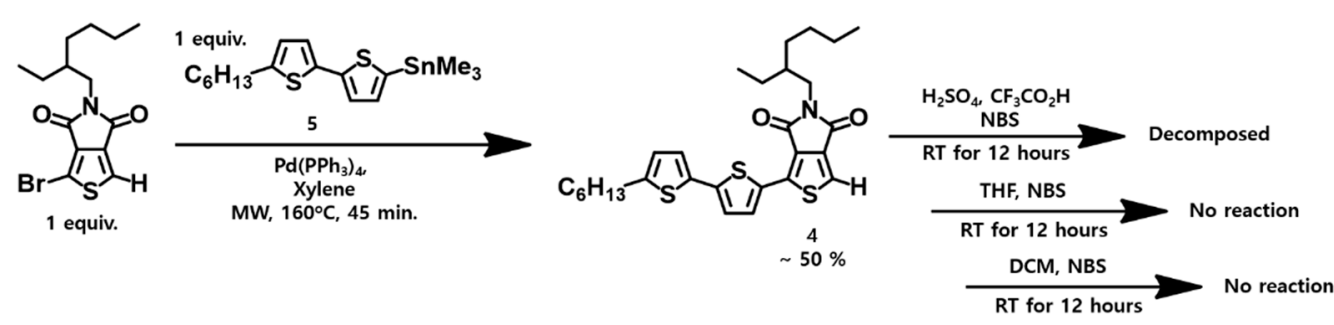

Scheme 3. Synthetic routes to (a) 6, 7, (b) 2, and (c) 4 . Some of the trials to get 2 from 4 by bromination included in (c) and the synthetic process for 2 in (b) were conducted with a microwave (MW) reactor.

Next, 4 and 3 were coupled to gain the M1 with a 12\% yield through direct C-H heteroarylation by modifying some of the methods for TPD-based polymers reported in the literature, as described in Scheme $4[58,61]$. Although the reaction conditions such as reaction time and temperature were varied without changing the Pd source and phosphine ligands, the chemical yield from this type of reaction was around $12 \%$; therefore, it was an atom economically unfavorable reaction. Since we believed there should be too many variable factors such as reagents and/or each fragment in Scheme 4 to optimize this type of reaction, it was, therefore, necessary to consider the other possible synthetic route to improve the chemical yield for M1. The alternative synthetic route was performed with specific reaction conditions, as shown in Scheme 5. While the previous synthetic route was designed by retrosynthesizing $\mathbf{M 1}$ from the side to the core, in Scheme 5, the synthetic procedure was alternated 
by expanding the core to side to reach the same target molecule. Initially, the 7 and 1 were coupled with $\operatorname{Pd}(0)$ catalyst for 8 that is core unit of $\mathbf{M 1}$ and then, the bromo derivatives of hexyl bithiophene (9) was coupled with the 8 as the core unit through the direct heteroanyllation method under conventional reflux conditions for $24 \mathrm{~h}$ instead of using a microwave reactor which was previously used. Therefore, since the final product was obtained with a much better yield than the procedure in Scheme 4 and 8 was also obtained with a better yield than $4(\sim 50 \%)$. We believe the alternative synthetic route, Scheme 5, could be a well-optimized synthetic route. Furthermore, to check the possibility to make M1 via a Stille cross-coupling reaction with 8 and 5 , the bromination reaction of 8 was attempted, as shown in Scheme 5, but the major brominated product was hexabromo 8 which was not a desired brominated product. Therefore, it is suggested that the total synthetic process of M1 could not be optimized with a Stille cross-coupling reaction by considering all the possible synthetic routes conducted in this study because it was hard to get 2 and the dibrominated 8 at the end of thiophene units.

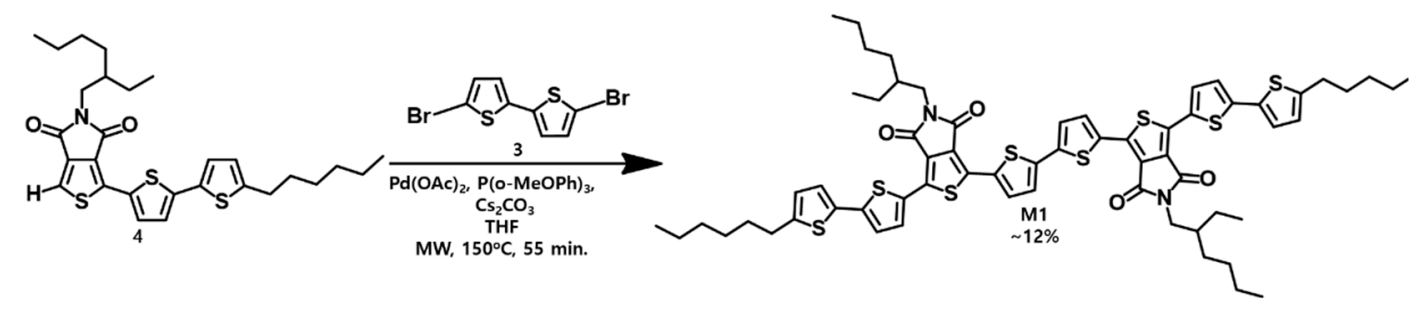

Scheme 4. Synthetic routes to M1 with 4 and 3 via direct heteroallyation.

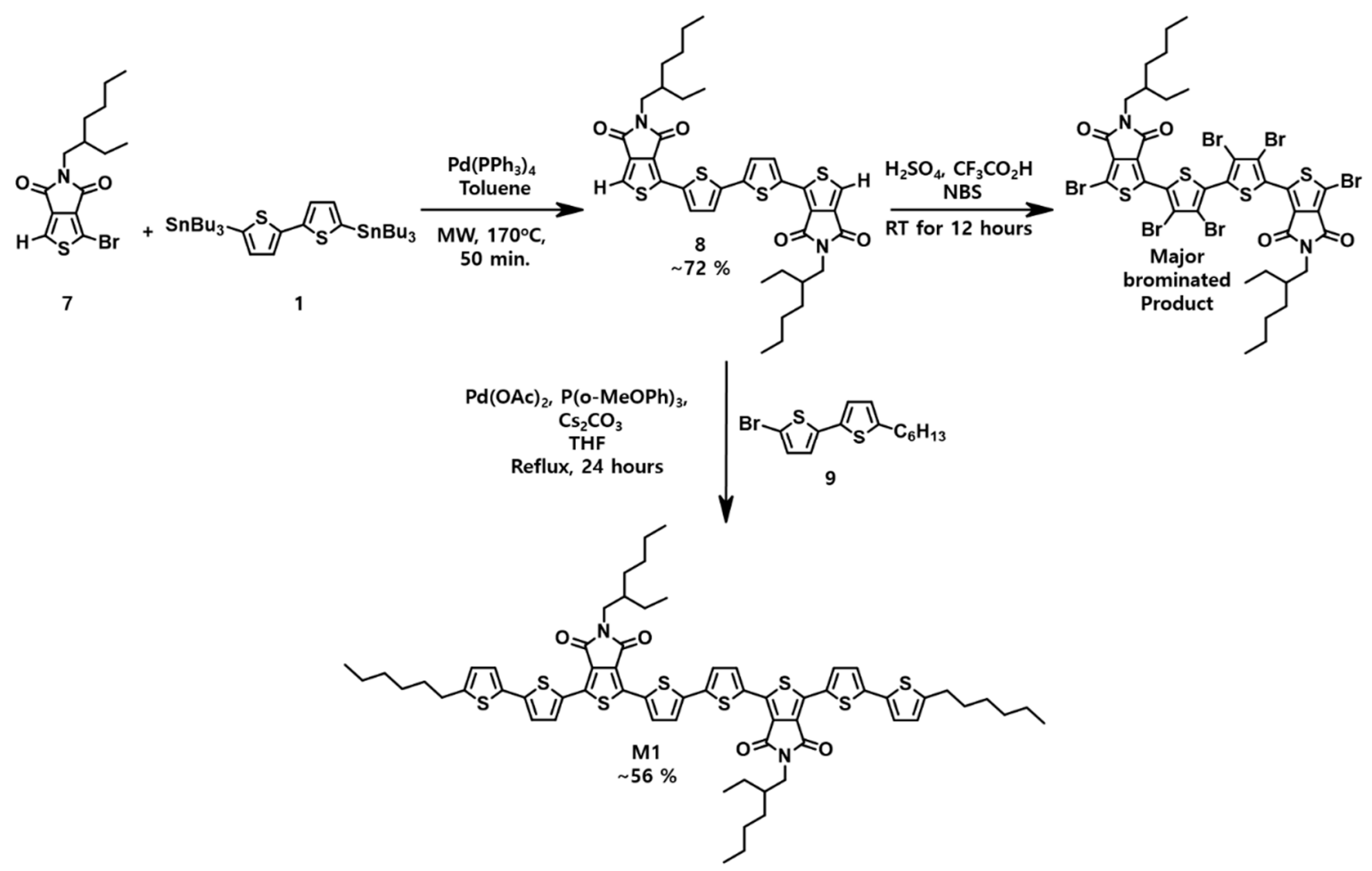

Scheme 5. Alternative total synthetic routes to M1.

\subsection{Optical, Electrochemical and Thermal Properties}

UV-vis absorption spectroscopy was used to investigate the optical properties of M1 in both the chloroform solution and the film spin-cast from $10 \mathrm{mg} / \mathrm{mL}$ chloroform solution at $1200 \mathrm{rpm}$ for one minute, see Figure 1a. In both solutions and films, M1 exhibits nearly identical absorption maxima at $508 \mathrm{~nm}$. The absorption onset of $\mathbf{M 1}$ in the film is red-shifted by approximately $100 \mathrm{~nm}$ relative to the onset of M1 from solution and the film also shows two broad vibronic shoulders at $542 \mathrm{~nm}$ and $600 \mathrm{~nm}$ 
indicating a strong tendency toward the aggregation of $\mathbf{M 1}$ with enhanced intermolecular $\pi-\pi$ contacts, corresponding to the increased electronic interaction between chromophores. The optical band gap $(1.82 \mathrm{eV})$ was calculated from the absorption onset at $680 \mathrm{~nm}$ of the material in the solid state.

a)

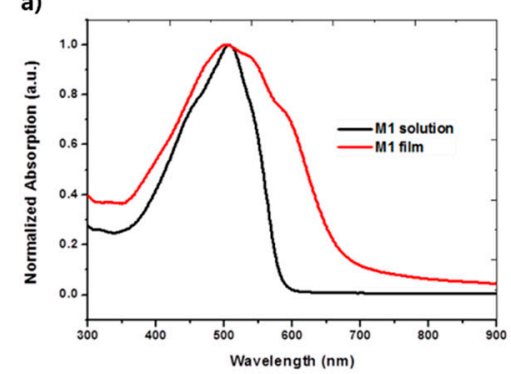

b)

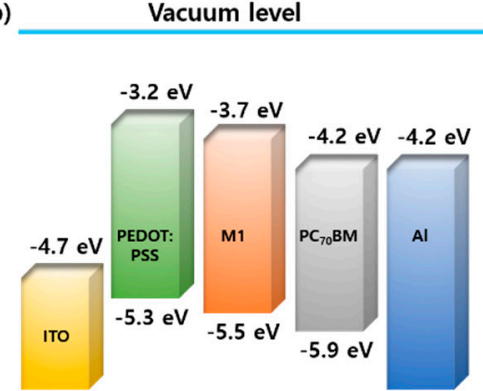

c)

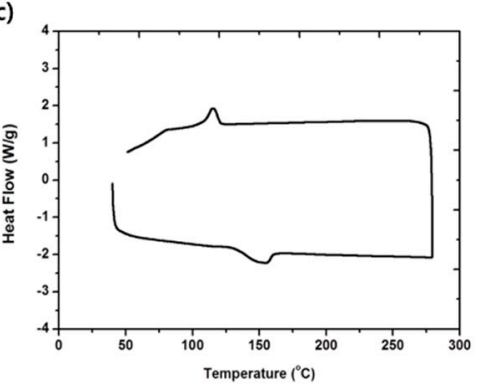

Figure 1. (a) UV-vis absorption spectra of M1 in the chloroform solution (black line) and of the film cast from the chloroform solution (red line), (b) Energy level diagram of all components in M1:PC ${ }_{70} \mathrm{BM}$ solar cells and (c) Differential scanning calorimetry (DSC) profile of M1.

Furthermore, the highest occupied molecular orbital (HOMO) and lowest unoccupied molecular orbital (LUMO) energy levels of M1 in the solid state were estimated by cyclic voltammetry (CV) measurements conducted on M1 films. Therefore, it was found that a relatively low HOMO level of $-5.54 \mathrm{eV}$ against vacuum level and LUMO level of $-3.66 \mathrm{eV}$ were obtained, and the estimated electrical band gap $(1.88 \mathrm{eV})$ is in reasonable agreement with the optical band gap $(1.82 \mathrm{eV})$. Hence, the energy levels of $\mathbf{M} 1$ in the solid state can be analyzed and the frontier orbital energies of all organic components in functioning organic photovoltaic devices can be illustrated in Figure $1 \mathrm{~b}$ together with each electrode such as indium tin oxide (ITO) on a glass substrate and aluminum (Al). Based on such an energy diagram, M1 can be well-defined as a p-type semiconductor (electron donor) when it is mixed with $\mathrm{PC}_{70} \mathrm{BM}$ (n-type semiconductor, electron acceptor) for a typical $\mathrm{BHJ}$ organic solar cell system. Furthermore, since the HOMO of $\mathbf{M 1}$ is quite close to that of $\mathrm{PC}_{70} \mathrm{BM}$, a large open circuit voltage $\left(V_{\mathrm{oc}}\right)$ can be expected and corresponds to the band alignment of LUMO levels between electron donors and acceptors. Efficient electron transfer between $\mathbf{M 1}$ and $\mathrm{PC}_{70} \mathrm{BM}$ would also be expected due to the fairly large difference [62]. Thermal phase transitions of M1 were studied by differential scanning calorimetry (DSC) and the results are shown in Figure 1c. The DSC thermogram shows that M1 exhibits a melting transition at $155^{\circ} \mathrm{C}$ and crystallizes at $115^{\circ} \mathrm{C}$. Therefore, it could be suggested that M1 has a strong tendency to form ordered aggregates with enhancing $\pi-\pi$ stacking in its solid state which can be attributed to the vibronic shoulder peak in its solid-state UV-vis profile [63].

\subsection{Photovoltaic Properties and Surface Morphologies of Blend Films}

We investigated the photovoltaic properties of $\mathbf{M 1}$ in BHJ solar cells prepared using different processing conditions. Certain parameters, such as the blend ratio between donor and acceptor, thermal treatment, processing solvent, and the use of additives, were varied. The influence of the M1:PC ${ }_{71} \mathrm{BM}$ blend ratio on photovoltaic performance is reflected in the current-voltage traces in Figure 2a and the results are summarized in Table 1. The devices were fabricated using the following architecture: ITO/PEDOT:PSS/M1:PC ${ }_{71} \mathrm{BM} / \mathrm{Al}$. The active layer was deposited by spin coating from $2 \%$ solutions in chloroform. Devices cast from chloroform using a M1:PC ${ }_{71} \mathrm{BM}$ blend ratio of 40:60 showed the best results for power conversion efficiency (PCE) $(0.89 \%)$ with a short-circuit current $\left(J_{\mathrm{sc}}\right)$ of $1.83 \mathrm{~mA} / \mathrm{cm}^{2}$, open circuit voltage $\left(V_{o c}\right)$ of $0.86 \mathrm{~V}$, and fill factor $(F F)$ of 0.57 . By substituting chlorobenzene for chloroform (also $2 \%$ solutions with the same M1:PC ${ }_{71} \mathrm{BM}$ ratio), the PCE improved to $1.23 \%\left(J_{\mathrm{sc}}=2.35 \mathrm{~mA} / \mathrm{cm}^{2}, V_{\mathrm{oc}}=0.86 \mathrm{~V}, F F=61 \%\right)$ [63]. The PCE values upon varying the blending ratio are a little higher than some devices fabricated with Poly(3-hexylthiophene) ( $\mathrm{P} 3 \mathrm{HT}$ ) and $\mathrm{PC}_{60} \mathrm{BM}$ in chloroform without post-treatment or processing additives [64]. 
a)

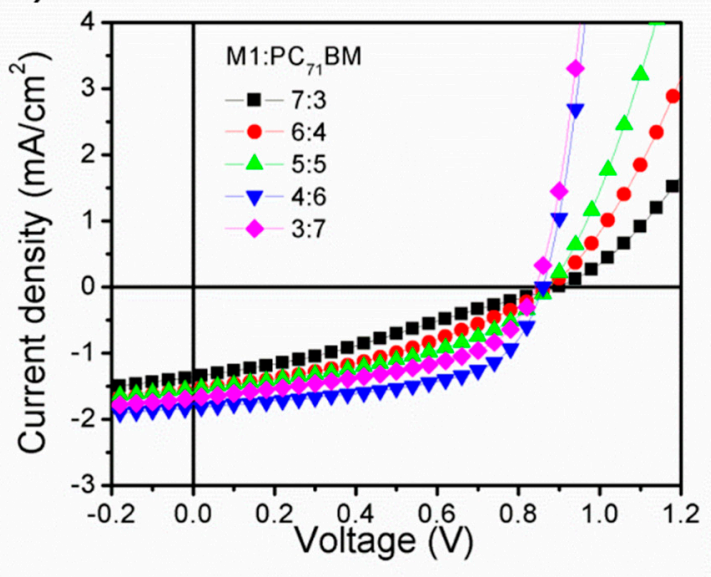

b)

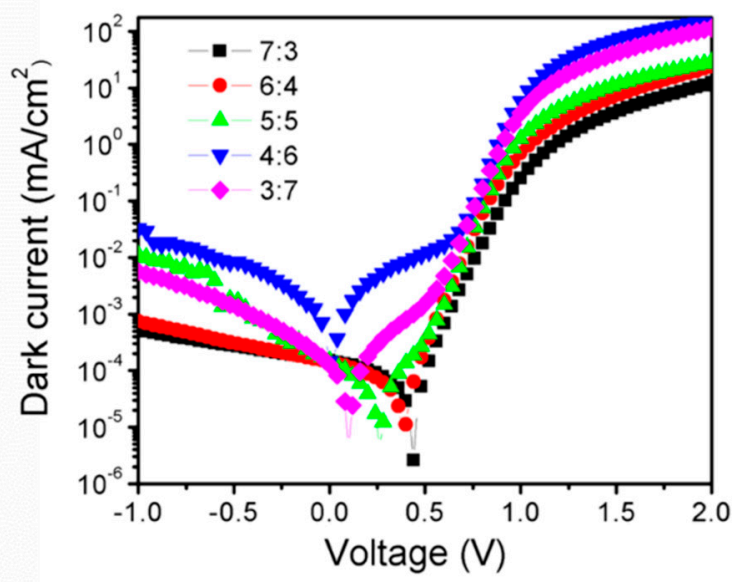

Figure 2. (a) Current-voltage (J-V) characteristics of BHJ solar cells based on M1:PC 71 BM active layers with different blend ratios cast from chloroform and (b) J-V curves in the dark based on the different blending ratio between $\mathbf{M} 1$ and $\mathrm{PC}_{71} \mathrm{BM}$.

Table 1. Summary of device parameters for SM-BHJ (small molecule -bulk heterojunction) solar cells based on M1:PC 71 BM active layers cast at different blend ratios from chloroform. All values are averaged from five devices with two electrodes on top of each device and a standard deviation within $\pm 4 \%$.

\begin{tabular}{|c|c|c|c|c|c|c|}
\hline $\mathrm{M1}: \mathrm{PC}_{71} \mathrm{BM}(w / w$ ratio in Chloroform) & $J_{\mathrm{sc}}\left(\mathrm{mA} / \mathrm{cm}^{2}\right)$ & $V_{\mathrm{oc}}(\mathrm{V})$ & $F F(\%)$ & PCE (\%) & $R_{s}\left(\Omega \cdot \mathrm{cm}^{2}\right)$ & $\mathbf{R}_{\mathrm{sh}}\left(\Omega \cdot \mathrm{cm}^{2}\right)$ \\
\hline $70: 30$ & 1.34 & 0.90 & 30 & 0.36 & 940 & $4.75 \times 10^{6}$ \\
\hline $60: 40$ & 1.55 & 0.87 & 37 & 0.50 & 430 & $3.23 \times 10^{6}$ \\
\hline $50: 50$ & 1.53 & 0.87 & 43 & 0.57 & 240 & $1.84 \times 10^{6}$ \\
\hline $40: 60$ & 1.83 & 0.86 & 57 & 0.89 & 70 & $0.14 \times 10^{6}$ \\
\hline $30: 70$ & 1.68 & 0.84 & 49 & 0.69 & 160 & $0.89 \times 10^{6}$ \\
\hline
\end{tabular}

We conducted a dark current analysis to analyze the charge recombination property of our synthesized organic photovoltaic materials in functioning devices, as shown in Figure 2b. From dark current analysis, series resistances were varying from 70 to $940 \mathrm{ohms}$ and shunt resistances were calculated from $0.14 \times 10^{6}$ to $4.75 \times 10^{6} \Omega \cdot \mathrm{cm}^{2}$. From the previous research, series and shunt resistors are associated with the recombination confirming that conventional organic solar cells (OSCs) show approximately $8.8 \Omega$ of series resistance and $0.87 \mathrm{k} \Omega$ of shunt resistance [65]. However, by comparing the conventional resistance values and those from M1-based devices, it can be noticed that the series resistances were 10-100 times higher than the typical OSC device systems. Therefore, we can expect that M1-based devices could have a relatively high recombination and all device characteristics were not optimized yet upon varying the blending ratio.

First, devices fabricated from chlorobenzene solutions represented improved PCEs relative to those obtained from chloroform solutions. Hence, it could be suggested that the solubility of M1 in chlorobenzene would be better than that in chloroform with an enhanced interface area between the D and A phases. Furthermore, the effect of solvent additives diiodooctane (DIO) and chloronaphthalene $(\mathrm{CN})$ on the performances of SM-BHJ solar cells based on M1:PC ${ }_{71} \mathrm{BM}(40: 60)$ active layers cast from $2 \%$ chlorobenzene solution were also studied, and these were reported in Figure 3 and Table 2. The PCEs with optimized devices attained for SM-BHJ solar cells in each case were $1.36 \%(0.2 \%$ DIO $)$ and $1.86 \%(0.5 \% \mathrm{CN})$, respectively, due to improved phase-separation between SM-donor and $\mathrm{PC}_{71} \mathrm{BM}$ acceptor. Especially, the solvent additive of $\mathrm{CN}$ exhibits much more efficient device performance than the DIO due to the better surface morphology, with reduced aggregation and uneven domains, which induced an increased interface area between D/A based on the atomic force microscopy (AFM) results, as shown in Figure 4. This result can also be attributed to the improved solubility of M1 with CN. 
(a)

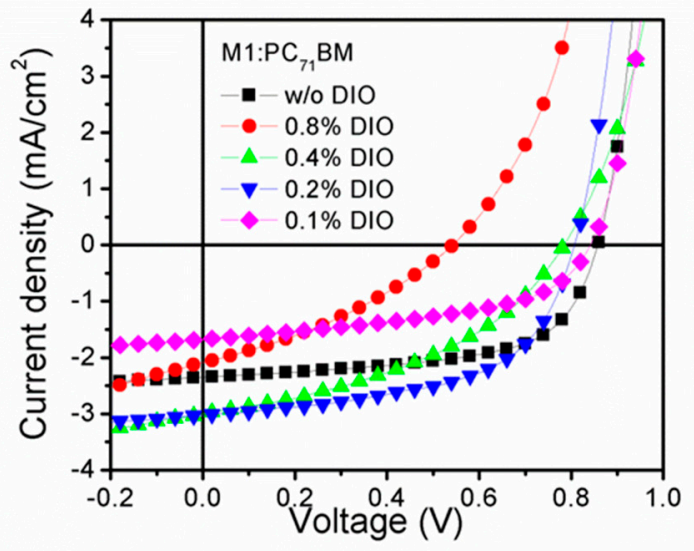

(b)

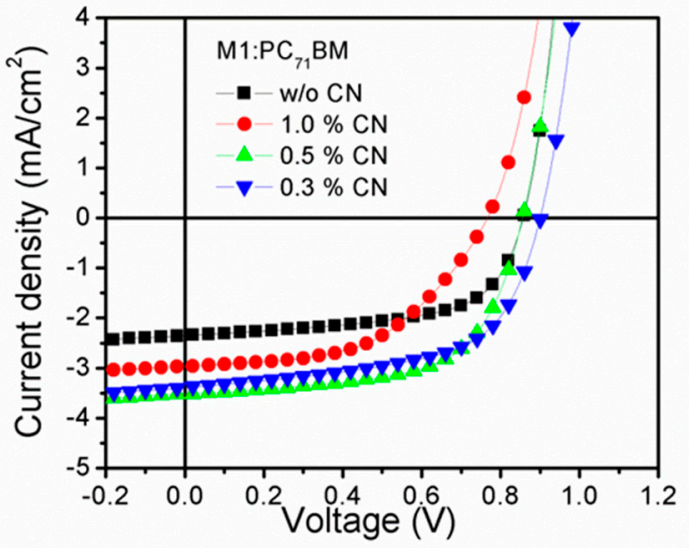

Figure 3. J-V characteristics of M1:PC ${ }_{71} \mathrm{BM}$ (40:60) solar cells cast from chlorobenzene incorporating different amounts of solvents additives: (a) 1,8-diiodooctane (DIO) and (b) chloronaphthalene (CN).

Table 2. Summary of device parameters of SM-BHJ solar cells based on M1:PC ${ }_{71} \mathrm{BM}$ active layers (40:60 in chlorobenzene) incorporating different amounts of DIO and $\mathrm{CN}$ additives. All values are averaged from five devices with two electrodes on top of each device and a standard deviation within $\pm 4 \%$.

\begin{tabular}{cccccc}
\hline M1:PC $_{\mathbf{7 1}} \mathbf{B M}(\mathbf{4 0 : 6 0 ,} w / w$ Ratio in Chlorobenzene) & $J_{\mathbf{s c}}\left(\mathbf{m A} / \mathbf{c m}^{2}\right)$ & $V_{\mathbf{o c}}(\mathrm{V})$ & FF (\%) & PCE (\%) \\
\hline No additives & & 2.35 & 0.86 & 61 & 1.23 \\
\hline & 0.8 & 2.09 & 0.54 & 34 & 0.38 \\
DIO $(\%, v / v)$ & 0.4 & 3.00 & 0.78 & 42 & 0.98 \\
& 0.2 & 3.03 & 0.81 & 56 & 1.36 \\
& 0.1 & 2.73 & 0.72 & 40 & 0.77 \\
\hline & 1.0 & 3.0 & 0.76 & 52 & 1.17 \\
& 0.5 & 3.53 & 0.85 & 62 & 1.86 \\
& 0.3 & 3.39 & 0.90 & 59 & 1.80 \\
\hline
\end{tabular}

(a)
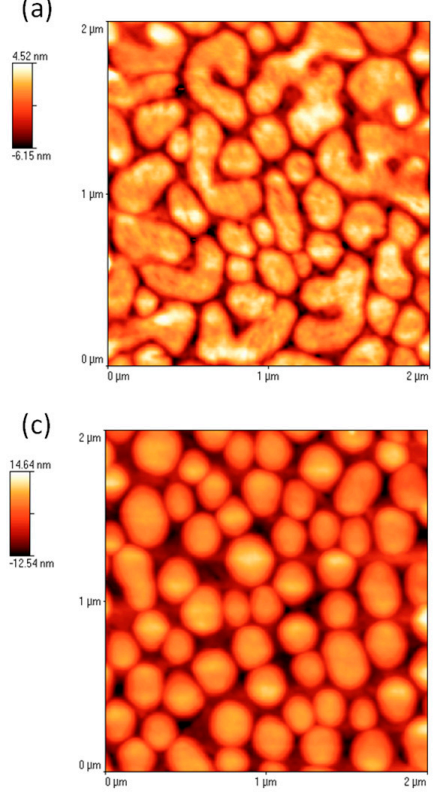

(b)

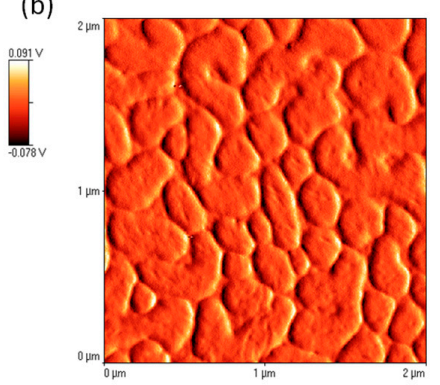

(d)

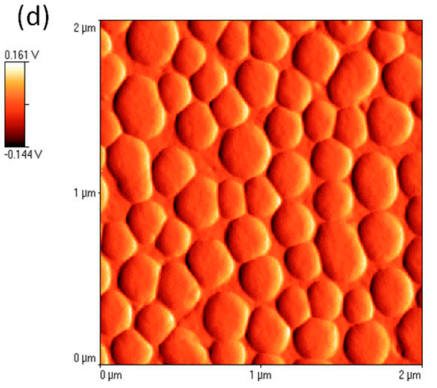

Figure 4. Surface topographic AFM images $(2 \mu \mathrm{m} \times 2 \mu \mathrm{m})$ of M1:PC 71 BM blend (40:60) films cast from $2 \%(w / v)$ chlorobenzene solution with (a) DIO $(0.2 \%, v / v)$ and (c) $\mathrm{CN}(0.5 \%, v / v)$, respectively. $(\mathbf{b}, \mathbf{d})$ Phase images corresponding to $(\mathbf{a}, \mathbf{c})$. 


\section{Conclusions}

In conclusion, M1, a TPD-based conjugated small molecule with a D-A-D-A-D framework, was synthesized and optimized with a combination of Stille cross-coupling and direct heteroallylation reaction. Some of the fragments for the target molecule showed low reactivity and low stability under the bromination conditions used in this study. Some stannylated or brominated fractions that can be easily obtained with more than $50 \%$ yield or are commercially available were conjugated by a Stille cross-coupling reaction while some fractions that were not simply brominated or stannlyated were coupled with direct allylation with an improved chemical yield. Therefore, we demonstrated the facile synthetic route applicable for various D-A-D-A-D with TPD derivatives. Furthermore, M1 shows strong absorption of visible light with an optical band gap of $1.82 \mathrm{eV}$ in the solid state and clear vibronic shoulders observed in the UV-vis absorption spectra of the M1 film suggesting a strong tendency to form $\pi-\pi$ stacking. Together with UV-vis, CV measurements demonstrated the excellent semiconducting properties of $\mathbf{M 1}$ for the organic $\mathrm{BHJ}$ solar cells by determining HOMO and LUMO energy levels. According to the concept of band alignment, as proven in $\mathrm{CV}$, series of $\mathrm{BHJ}$ solar cell devices were fabricated with $\mathrm{PC}_{71} \mathrm{BM}$ upon varying the blend ratio between $\mathrm{M} 1$ and $\mathrm{PC}_{71} \mathrm{BM}$, solvents, and the type of additives so that M1 showed fairly stable p-type semiconducting properties with the highest PCE of $1.86 \%, V_{\mathrm{oc}}$ of $0.85 \mathrm{eV}, J_{\mathrm{sc}}$ of $3.53 \mathrm{~mA} / \mathrm{cm}^{2}$, and FF of $62 \%$ achieved in this study. These moderated PCEs of M1:PC ${ }_{71} \mathrm{BM}$ BHJ solar cells relative to polymers and other types of small-molecule $\mathrm{BHJ}$ solar cells appear to be caused by uneven surface morphologies of M1:PC $\mathrm{C1}_{11} \mathrm{BM}$. Therefore, from a broader perspective, this contribution implies that a wider choice of solvents and additives may be pursued to address the challenge in obtaining targeted $\mathrm{BHJ}$ morphologies.

Author Contributions: Performed the preparation and characterization of materials: O.K.; the fabrication and characterization of BHJ solar cells: J.L.; designed the material concepts in this study and drafted the manuscript: J.K.P.; designed BHJ solar cell concepts and also drafted the manuscript: D.H.W.

Funding: This research was funded by the Hankuk University of Foreign Studies Research Fund of 2018. This research was also supported by the Chung-Ang University Research Scholarship Grants in 2018.

Conflicts of Interest: The authors declare no conflict of interest.

\section{References}

1. Thompson, B.C.; Fréchet, J.M.J. Polymer-fullerene composite solar cells. Angew. Chem. Int. Ed. 2008, 47, 58-77. [CrossRef] [PubMed]

2. Dennler, G.; Scharber, M.C.; Brabec, C.J. Polymer-Fullerene Bulk-Heterojunction Solar Cells. Adv. Mater. 2009, 21, 1323-1338. [CrossRef]

3. Günes, S.; Neugebauer, H.; Sariciftci, N.S. Conjugated Polymer-Based Organic Solar Cells. Chem. Rev. 2007, 107, 1324-1338. [CrossRef] [PubMed]

4. Arias, A.C.; MacKenzie, J.D.; McCulloch, I.; Rivany, J.; Salleo, A. Materials and Applications for Large Area Electronics: Solution-Based Approaches. Chem. Rev. 2010, 110, 3-24. [CrossRef] [PubMed]

5. Espinosa, N.; Hosel, M.; Angmo, D.; Krebs, F. Solar cells with one-day energy payback for the factories of the future. Energy Environ. Sci. 2012, 5, 5117-5132. [CrossRef]

6. Zhou, H.; Yang, L.; You, W. Rational Design of High Performance Conjugated Polymers for Organic Solar Cells. Macromolecules 2012, 45, 607-632. [CrossRef]

7. Facchetti, A. $\pi$-Conjugated Polymers for Organic Electronics and Photovoltaic Cell Applications. Chem. Mater. 2011, 23, 733-758. [CrossRef]

8. Beaujuge, P.M.; Fréchet, J.M.J. Molecular Design and Ordering Effects in $\pi$-Functional Materials for Transistor and Solar Cell Applications. J. Am. Chem. Soc. 2011, 133, 20009-20029. [CrossRef]

9. Amb, C.M.; Chen, S.; Graham, K.R.; Subbiah, J.; Small, C.E.; So, F.; Reynolds, J.R. Dithienogermole as a fused electron donor in bulk heterojunction solar cells. J. Am. Chem. Soc. 2011, 133, 10062-10065. [CrossRef]

10. Gendron, D.; Leclerc, M. New conjugated polymers for plastic solar cells. Energy Environ. Sci. 2011, 4, 1225-1237. [CrossRef] 
11. Zhou, H.; Yang, L.; Stuart, A.C.; Price, S.C.; Liu, S.; You, W. Development of fluorinated benzothiadiazole as a structural unit for a polymer solar cell of $7 \%$ efficiency. Angew. Chem. Int. Ed. 2011, 50, 2995-2998. [CrossRef] [PubMed]

12. Price, S.C.; Stuart, A.C.; Yang, L.; Zhou, H.; You, W. Fluorine substituted conjugated polymer of medium band gap yields 7\% efficiency in polymer-fullerene solar cells. J. Am. Chem. Soc. 2011, 133, 4625-4631. [CrossRef] [PubMed]

13. Chu, T.-Y.; Lu, J.; Beaupre, S.; Zhang, Y.; Pouliot, J.-R.M.; Wakim, S.; Zhou, J.; Leclerc, M.; Li, Z.; Ding, J.; et al. Bulk Heterojunction Solar Cells Using Thieno[3,4-c]pyrrole-4,6-dione and Dithieno[3,2-b:2', $\left.3^{\prime}-d\right]$ silole Copolymer with a Power Conversion Efficiency of 7.3\%. J. Am. Chem. Soc. 2011, 133, 4250-4253. [CrossRef] [PubMed]

14. He, Z.; Zhong, C.; Huang, X.; Wong, W.-Y.; Wu, H.; Chen, L.; Su, S.; Cao, Y. Simultaneous enhancement of open-circuit voltage, short-circuit current density, and fill factor in polymer solar cells. Adv. Mater. 2011, 23, 4636-4643. [CrossRef] [PubMed]

15. Li, X.; Choy, W.C.; Huo, L.; Xie, F.; Sha, W.E.; Ding, B.; Guo, X.; Li, Y.; Hou, J.; You, J.; et al. Dual plasmonic nanostructures for high performance inverted organic solar cells. Adv. Mater. 2012, 24, 3046-3052. [CrossRef] [PubMed]

16. Service, R.F. Solar energy. Outlook brightens for plastic solar cells. Science 2011, 332, 6027. [CrossRef] [PubMed]

17. Small, C.E.; Chen, S.; Graham, K.R.; Subbiah, J.; Amb, C.M.; Tseng, S.W.; Lai, T.H.; Reynolds, J.R.; So, F. High-efficiency inverted dithienogermole-thienopyrrolodione-based polymer solar cells. Nat. Photonics 2012, 6, 115-120. [CrossRef]

18. Cheng, Y.-J.; Yang, S.-H.; Hsu, C.-S. Synthesis of Conjugated Polymers for Organic Solar Cell Applications. Chem. Rev. 2009, 109, 5868-5923. [CrossRef]

19. Zhang, W.; Smith, J.; Watkins, S.E.; Gysel, R.; McGehee, M.; Salleo, A.; Kirkpatrick, J.; Ashraf, S.; Anthopoulos, T.; Heeney, M.; et al. Indacenodithiophene Semiconducting Polymers for High-Performance, Air-Stable Transistors. J. Am. Chem. Soc. 2010, 132, 11437-11439. [CrossRef]

20. Zhang, M.; Tsao, H.N.; Pisula, W.; Yang, C.; Mishra, A.K.; Müllen, K. Field-Effect Transistors Based on a Benzothiadiazole-Cyclopentadithiophene Copolymer. J. Am. Chem. Soc. 2007, 129, 3472-3473. [CrossRef]

21. Tsao, H.N.; Cho, D.M.; Park, I.; Hansen, M.R.; Mavrinskiy, A.; Yoon, D.Y.; Graf, R.; Pisula, W.; Spiess, H.W.; Müllen, K. Ultrahigh mobility in polymer field-effect transistors by design. J. Am. Chem. Soc. 2011, 133, 2605-2612. [CrossRef]

22. Bijleveld, J.C.; Shahid, M.; Gilot, J.; Wienk, M.M.; Janssen, R.A.J. Copolymers of Cyclopentadithiophene and Electron-Deficient Aromatic Units Designed for Photovoltaic Applications. Adv. Funct. Mater. 2009, 19, 3262-3270. [CrossRef]

23. Bijleveld, J.C.; Zoombelt, A.P.; Mathijssen, S.G.J.; Wienk, M.M.; Turbiez, M.; de Leeuw, D.M.; Janssen, R.A.J. Poly(diketopyrrolopyrrole-terthiophene) for Ambipolar Logic and Photovoltaics. J. Am. Chem. Soc. 2009, 131, 16616-16617. [CrossRef] [PubMed]

24. Bijleveld, J.C.; Gevaerts, V.S.; Nuzzo, D.D.; Turbiez, M.; Mathijssen, S.G.J.; de Leeuw, D.M.; Wienk, M.M.; Janssen, R.A.J. Efficient Solar Cells Based on an Easily Accessible Diketopyrrolopyrrole Polymer. Adv. Mater. 2010, 22, E242-E246. [CrossRef] [PubMed]

25. Roncali, J. Molecular Bulk Heterojunctions: An Emerging Approach to Organic Solar Cells. Acc. Chem. Res. 2009, 42, 1719-1730. [CrossRef] [PubMed]

26. Walker, B.; Kim, C.; Nguyen, T.-Q. Small Molecule Solution-Processed Bulk Heterojunction Solar Cells. Chem. Mater. 2011, 23, 470-482. [CrossRef]

27. Li, Y.; Guo, Q.; Li, Z.; Pei, J.; Tian, W. Solution processable D-A small molecules for bulk-heterojunction solar cells. Energy Environ. Sci. 2010, 3, 1427-1436. [CrossRef]

28. Riede, M.; Mueller, T.; Tress, W.; Schueppel, R.; Leo, K. Small-molecule solar cells-status and perspectives. Nanotechnology 2008, 19, 424001-424013. [CrossRef]

29. Hains, A.W.; Liang, Z.; Woodhouse, M.A.; Gregg, B.A. Molecular semiconductors in organic photovoltaic cells. Chem. Rev. 2010, 110, 6689-6735. [CrossRef]

30. Broggi, A.; Tomasi, I.; Bianchi, L.; Marrochi, A.; Vaccaro, L. Small molecular aryl acetylenes: Chemically thailoring high-efficiency organic semiconductors for solar cells and field-effect transistors. ChemPlusChem 2014, 79, 486-508. [CrossRef] 
31. Burckstummer, H.; Kronenberg, N.M.; Gsanger, M.; Stolte, M.; Meerholz, K.; Wurthner, F. Tailored merocyanine dyes for solution-processed BHJ solar cells. J. Mater. Chem. 2010, 20, 240-243. [CrossRef]

32. Bagnis, D.; Beverine, L.; Huang, H.; Silvestri, F.; Yao, Y.; Yan, H.; Pagani, G.A.; Marks, T.J.; Facchetti, A. Marked Alkyl- vs. Alkenyl-Substitutent Effects on Squaraine Dye Solid-State Structure, Carrier Mobility, and Bulk-Heterojunction Solar Cell Efficiency. J. Am. Chem. Soc. 2010, 132, 4074-4075. [CrossRef] [PubMed]

33. Mayerhoffer, U.; Deing, K.; Gruss, K.; Braunschweig, H.; Meerholz, K.; Wurthner, F. Outstanding short-circuit currents in BHJ solar cells based on NIR-absorbing acceptor-substituted squaraines. Angew. Chem. Int. Ed. 2009, 48, 8776-8779. [CrossRef]

34. Wei, G.D.; Lunt, R.R.; Sun, K.; Wang, S.Y.; Thompson, M.E.; Forrest, S.R. Efficient, ordered bulk heterojunction nanocrystalline solar cells by annealing of ultrathin squaraine thin films. Nano Lett. 2010, 10, 3555-3559. [CrossRef] [PubMed]

35. Ilmi, R.; Haque, A.; Khan, M.S. High efficiency small molecule-based donor materials for organic solar cells. Org. Electron. 2018, 58, 53-62. [CrossRef]

36. Bin, H.; Yao, J.; Yang, Y.; Angunawela, I.; Sun, C.; Gao, L.; Ye, L.; Qiu, B.; Xue, L.; Zhu, C.; et al. High-efficiency all-small-molecule organic solar cells based on an organic molecule donor with alkylsily-thienyl conjugated side chains. Adv. Mater. 2018, 30, 1706361-1706368. [CrossRef] [PubMed]

37. Lloyd, M.T.; Anthony, J.E.; Malliaras, G.G. Photovoltaics from soluble small molecules. Mater. Today 2007, 10, 34-41. [CrossRef]

38. Shang, H.; Fan, H.; Liu, Y.; Hu, W.; Li, Y.; Zhan, X. A solution-processable star-shaped molecule for high-performance organic solar cells. Adv. Mater. 2011, 23, 1554-1557. [CrossRef]

39. Zhang, F.; Wu, D.; Xu, Y.; Feng, X. Thiophene-based conjugated oligomers for organic solar cells. J. Mater. Chem. 2011, 21, 17590-17600. [CrossRef]

40. Feng, G.; Xu, Y.; Zhang, J.; Wang, Z.; Zhou, Y.; Li, Y.; Wei, Z.; Li, C.; Li, W. All-small-molecule organic solar cells based on electron donor incorporating binary electron deficient units. J. Mater. Chem. 2016, 4, 6056-6063. [CrossRef]

41. Chen, Y.; Wan, X.; Long, G. High performance photovoltaic applications using solution-processed small molecules. Acc. Chem. Res. 2013, 46, 2645-2655. [CrossRef] [PubMed]

42. Lee, O.P.; Yiu, A.T.; Beaujuge, P.M.; Woo, C.H.; Holcomb, T.W.; Millstone, J.E.; Douglas, J.D.; Chen, M.S.; Fréchet, J.M.J. Efficient small molecule bulk heterojunction solar cells with high fill factors via pyrene-directed molecular self-assembly. Adv. Matter. 2011, 23, 5359-5363. [CrossRef] [PubMed]

43. Mikroyannidis, J.A.; Stylianakis, M.M.; Dong, Q.; Zhou, Y.; Tian, W. New 4,7-dithienobenzothiadiazole derivatives with cyano-vinylene bonds: synthesis, photophysics and photovoltaics. Syn. Met. 2009, 159, 1471-1477. [CrossRef]

44. Lin, L.-Y.; Lu, C.-W.; Huang, W.-C.; Chen, Y.-H.; Lin, H.-W.; Wong, K.-T. New A-A-D-A-A-type electron donors for small molecule organic solar cells. Org. Lett. 2011, 13, 4962-4965. [CrossRef] [PubMed]

45. Shi, Q.; Cheng, P.; Li, Y.; Zhan, X. A Solution Processable D-A-D Molecule based on Thiazolothiazole for High Performance Organic Solar Cells. Adv. Energy Mater. 2012, 2, 63-67. [CrossRef]

46. McDowell, C.; Abdelsamie, M.; Toney, M.F.; Bazan, G.C. Solvent Additives: Key morphology-directing agents for solution-processed organic solar cells. Adv. Mater. 2018, 30, 1707114-1707143. [CrossRef]

47. Liu, X.; Huettner, S.; Rong, Z.; Sommer, M.; Friend, R.H. Solvent additive control of morphology and crystallization in semiconducting polymer blends. Adv. Mater. 2014, 24, 669-674. [CrossRef]

48. Liao, H.-C.; Ho, C.-C.; Chan, C.-Y.; Jao, M.-H.; Darling, S.B.; Su, W.-F. Additives for morphology control in high-efficiency organic solar cells. Mater. Today 2013, 16, 326-336. [CrossRef]

49. Henson, Z.B.; Welch, G.C.; van der Poll, T.; Bazan, G.C. Pyridalthiadiazole-Based Narrow Band Gap Chromophores. J. Am. Chem. Soc. 2012, 134, 3766-3779. [CrossRef]

50. Takacs, C.J.; Sun, Y.; Welch, G.C.; Perez, L.A.; Liu, X.; Wen, W.; Bazan, G.C.; Heeger, A.J. Solar cell efficiency, self-assembly, and dipole-dipole interactions of isomorphic narrow-band-gap molecules. J. Am. Chem. Soc. 2012, 134, 16597-16606. [CrossRef]

51. Welch, G.C.; Bakus, R.C., II; Teat, S.J.; Bazan, G.C. Impact of regiochemistry and isoelectronic bridgehead substitution on the molecular shape and bulk organization of narrow bandgap chromophores. J. Am. Chem. Soc. 2013, 135, 2298-2305. [CrossRef] [PubMed]

52. Zou, Y.; Najari, A.; Berrouard, P.; Beaupré, S.; Aïch, B.R.; Tao, Y.; Leclerc, M. A thieno[3,4-c]pyrrole-4,6-dione-based copolymer for efficient solar cells. J. Am. Chem. Soc. 2010, 132, 5330-5331. [CrossRef] [PubMed] 
53. Piliego, C.; Holcombe, T.W.; Douglas, J.D.; Woo, C.H.; Beaujuge, P.M.; Fréchet, J.M.J. Synthetic control of structural order in N-alkylthieno[3,4-c]pyrrole-4,6-dione-based polymers for efficient solar cells. J. Am. Chem. Soc. 2010, 132, 7595-7597. [CrossRef] [PubMed]

54. Su, M.-S.; Kuo, C.-Y.; Yuan, M.-C.; Jeng, U.-S.; Su, C.-J.; Wei, K.-H. Improving device efficiency of polymer/fullerene bulk heterojunction solar cells through enhanced crystallinity and reduced grain boundaries induced by solvent additives. Adv. Mater. 2011, 23, 3315. [CrossRef] [PubMed]

55. Jo, J.; Pron, A.; Berrouard, P.; Leong, W.L.; Yuen, J.D.; Moon, J.S.; Leclerc, M.; Heeger, A.J. A New Terthiophene-Thienopyrrolodione Copolymer-Based Bulk Heterojunction Solar Cell with High Open-Circuit Voltage. Adv. Energy Mater. 2012, 2, 1397-1403. [CrossRef]

56. Chen, G.-Y.; Cheng, Y.-H.; Chou, Y.-J.; Su, M.-S.; Chen, C.-M.; Wei, K.-H. Crystalline conjugated polymer containing fused 2,5-di(thiophen-2-yl)thieno[2,3-b]thiophene and thieno[3,4-c]pyrrole-4,6-dione units for bulk heterojunction solar cells. Chem. Commun. 2011, 47, 5064-5066. [CrossRef] [PubMed]

57. Pron, A.; Berrouard, P.; Leclerc, M. Thieno[3,4-c]pyrrole-4,6-dione-Based Polymers for Optoelectronic Applications. Macromol. Chem. Phys. 2013, 214, 7-16. [CrossRef]

58. Berrouard, P.; Dufresne, S.; Pron, A.; Veilleux, J.; Leclerc, M. Low-Cost Synthesis and Physical Characterization of Thieno[3,4-c]pyrrole-4,6-dione-Based Polymers. J. Org. Chem. 2012, 77, 8167-8173. [CrossRef] [PubMed]

59. Yuan, M.-C.; Chiu, M.-Y.; Liu, S.-P.; Chen, C.-M.; Wei, K.-H. A Thieno[3,4-c]pyrrole-4,6-dione-Based Donor-Acceptor Polymer Exhibiting High Crystallinity for Photovoltaic Applications. Macromolecules 2010, 43, 6936-6938. [CrossRef]

60. Lin, Y.; Cheng, P.; Liu, Y.; Zhao, X.; Li, D.; Tan, J.; Hu, W.; Li, Y.; Zhan, X. Solution-processable small molecules based on thieno[3,4-c]pyrrole-4,6-dione for high-performance solar cells. Sol. Energy Mater. Sol. Cells 2012, 99, 301-307. [CrossRef]

61. Berrouard, P.; Najari, A.; Pron, A.; Gendron, D.; Morin, P.-O.; Pouliot, J.-R.; Veilleux, J.; Leclerc, M. Synthesis of 5-alkyl[3,4-c]thienopyrrole-4,6-dione-based polymers by direct heteroarylation. Angew. Chem. Int. Ed. 2011, 51, 2068-2071. [CrossRef] [PubMed]

62. Park, J.K.; Kim, C.; Walker, B.; Nguyen, T.-Q.; Seo, J.H. Morphology control of solution processable small molecule bulk heterojunction solar cellsviasolvent additives. RSC Adv. 2012, 2, 2232-2234. [CrossRef]

63. Kwon, O.; Park, S.; Park, J.K.; Wang, D.H. Controlling the optoelectronic properties of narrow bandgap organic chromophores upon isoelectronic bridgehead substitution. Dyes Pigment. 2018, 158, 233-239. [CrossRef]

64. Dang, M.T.; Wantz, G.; Bejbouji, H.; Urien, M.; Dautel, O.J.; Vignau, L.; Hirsch, L. Polymeric solar cells based on P3HT:PCBM: role of the casting solvent. Sol. Energy Mater. Sol. Cells 2011, 95, 3408-3418. [CrossRef]

65. Dhass, A.D.; Natarajan, E.; Lakshmi, P. Influence of shunt resistance on the performance of solar photovoltaic cell. In Proceedings of the 2012 International Conference on Emerging Trends in Electrical Engineering and Energy Management (ICETEEEM), Chennai, India, 13-15 December 2012; pp. 382-386. 